Revista Destaques Acadêmicos, Lajeado, v. 10, n. 2, 2018. ISSN 2176-3070

DOI: http://dx.doi.org/10.22410/issn.2176-3070.v10i2a2018.1743

http://www.univates.br/revistas

\title{
DA CORREIÇÃO PARCIAL: CONSIDERAÇÕES DOUTRINÁRIAS E JURISPRUDENCIAIS
}

\author{
Cláudia Daniela Behrens ${ }^{1}$
}

Resumo: A correição parcial é instrumento de grande relevância no processo penal, uma vez que viabiliza a impugnação de decisões judiciais que causem prejuízo à parte, bem como busca repelir a inversão de atos e, inclusive, tumultos processuais, e que não sejam impugnáveis por outros recursos. Ademais, sendo medida que se limita a corrigir o trâmite processual viciado, não possui amparo constitucional, embora haja previsão na Lei 5.010/1966 no que tange à existência deste instituto. Inobstante, quanto ao processamento da medida, adota-se mormente o rito do Recurso em Sentido em Estrito, capitulado no Código de Processo Penal, observando-se os prazos referentes a este recurso, embora haja correntes doutrinárias defendendo pela aplicação do rito do Agravo de Instrumento, previsto no Código de Processo Civil. Atinente aos efeitos, apresenta a correição o efeito devolutivo, além do efeito regressivo atualmente introduzido pela jurisprudência. Podem interpor a correição parcial as partes, interessados, o Ministério Público e o Corregedor-Geral de Justiça, para fins de impugnação dos atos de juízes de primeira instância.

Palavras-chave: Correição Parcial. Repulsa. Decisões judiciais prejudiciais. Tumulto processual. Inversão de atos.

\section{INTRODUÇÃO}

$\mathrm{O}$ artigo em liça tem por escopo apresentar e delinear as principais características, funções, possibilidades e forma de impugnação das decisões jurisdicionais através da correição parcial, no âmbito do processo penal, medida tal que visa sanar eventuais erros cometidos pelo magistrado em seus julgados. Lado outro, trará uma breve análise acerca da sua (in)constitucionalidade, bem como alguns parâmetros históricos desde o seu surgimento, até os dias de hoje, além de versar acerca de sua natureza jurídica e outras questões reflexas neste tema.

1 Acadêmica do Curso de Direito da Universidade do Vale do Taquari (UNIVATES). Bolsista no Tribunal de Justiça do Rio Grande do Sul. 
Também, verificando-se os efeitos, prazos, previsão legal e ritos processuais adotados, discorro neste artigo sobre paradigmas doutrinários e jurisprudenciais, pelo que selecionados aparatos teóricos e práticos neste meio, a fim de esposar uma abordagem prática, que possibilite uma maior compreensão do tema, tendo em vista a sua relevância jurídica.

Outrossim, a metodologia utilizada neste trabalho é a exploratória, que visa aprimorar ideias, bem como desenvolver o tema, ora instigado, ensejando, por consequência, uma maior compreensão do assunto abordado. Ademais, trata-se de pesquisa bibliográfica, que possui base em livros, doutrinas, artigos, bem como demais materiais elaborados por profissionais e juristas atuantes no meio jurídico.

A fim de alcançar os objetivos propostos, este artigo apresenta as seguintes subdivisões: Conceito; Abordagem Histórica; Natureza Jurídica; Previsão Legal; Da (In)Constitucionalidade da Correição Parcial; Da Legitimidade Ativa e Passiva; Do Rito Processual; Prazo; Do processamento; Efeitos; Considerações Finais.

\section{CONCEITO}

Sinopticamente, a correição parcial trata-se de medida cabível contra ato do julgador que, ou por erro ou por abuso de poder, incorre na modalidade de error in procedendo ${ }^{2}$, ou seja, o ato do magistrado está eivado de vício e, por conseguinte, vem a gerar a inversão dos atos processuais, bem como eventual extrapolação abusiva de prazos ou sobrestamento injustificado de feitos.

Nas palavras do ilustre estudioso Avena (texto digital, 2015): “(...) medida cabível contra ato de magistrado que, por erro ou abuso de poder, acarretar inversão tumultuária dos atos processuais, dilatação abusiva de prazos ou paralisação injustificada de feitos."

Nucci (texto digital, 2015), em contrapartida, defende ser a correição parcial um recurso com a finalidade de corrigir erros de procedimento que foram adotados pelo magistrado de primeira instância, durante o trâmite processual. Assim, em razão de haver uma "inversão tumultuária dos atos e fórmulas legais", apresenta natureza residual, apenas sendo pertinente o seu uso quando inexistir qualquer outro recurso específico ao caso concreto previsto em lei (art. 6. ${ }^{\circ}$, I, Lei 5.010/66).

Nesta linha, destaco a seguinte ementa, que enfatiza a característica residual da correição parcial:

2 Caracteriza-se como erro no proceder, visto que é um vício de forma, extrínseco, de uma decisão judicial, estando sempre relacionado a questões processuais. (SILVA, texto digital, 2009). 
CORREIÇÃO PARCIAL. DECISÃO QUE NÃO RECEBEU AGRAVO EM EXECUÇÃO. HIPÓTESE DE INTERPOSIÇÃO DE CARTA TESTEMUNHÁVEL. INAPLICABILIDADE DO PRINCÍPIO DA FUNGIBILIDADE. A decisão que não recebe o Agravo em Execução, por adotar o rito do Recurso em Sentido Estrito, desafia a interposição de carta testemunhável. A correição parcial, por sua vez, é medida residual, pois utilizada quando inexistente outro recurso previsto em lei. No caso, inviável a aplicação do princípio da fungibilidade recursal, pois não observado o prazo do recurso cabível, previsto no artigo 640 do Código de Processo Penal. CORREIÇÃo PARCIALNÃO CONHECIDA. (Correição Parcial N $N^{\circ}$ 70069612695, Primeira Câmara Criminal, Tribunal de Justiça do RS, Relator: Jayme Weingartner Neto, Julgado em 08/06/2016) (grifei)

Também, em recentes decisões do Egrégio Tribunal de Justiça do Rio Grande do Sul, vislumbra-se que:

CORREIÇÃO PARCIAL. INVERSÃO TUMULTUÁRIA. PRAZO SUCESSIVO. APRESENTAÇÃO DE MEMORIAIS. ART. 403, CAPUT, E $\S 3^{\circ}$, DO CPP. Decisão judicial que após o encerramento da instrução, determina a abertura de vista sucessiva dos autos às partes, condicionando a apresentação dos memoriais, tanto da acusação, quanto das defesas, na mesma data, ao final. $\mathrm{O}$ art. 403, caput, e $\S 3^{\circ}$, do CPP, no entanto, expõe a lógica da ordem processual a ser seguida, verificando-se no caput do dispositivo em tela, que a manifestação da acusação precede à da defesa, o que obviamente remete a aplicação do princípio do contraditório, igualmente existente na hipótese mencionada no parágrafo terceiro do referido artigo. Inversão tumultuária caracterizada. CORREIÇÃO PROCEDENTE. (Correição Parcial N 70075406900 , Quarta Câmara Criminal, Tribunal de Justiça do RS, Relator: Julio Cesar Finger, Julgado em 09/11/2017) (grifei)

CORREIÇÃO PARCIAL. DECISÃO QUE DEIXOU DE DESIGNAR AUDIÊNCIA E DETERMINOU O SOBRESTAMENTO DO FEITO DIANTE DA DECISÃO DO PLENÁRIO DO STF QUE, APRECIANDO RECURSO ESPECIAL, RECONHECEU EXISTÊNCIA DE REPERCUSSÃO GERAL EM RELAÇ̃̃O À ATIPICIDADE DO PORTE DE DROGA PARA CONSUMO PESSOAL. O reconhecimento de repercussão geral não implica sobrestamento das ações penais que versem sobre a mesma matéria, não podendo o juízo determiná-lo sem prévia determinação do Ministro Relator do paradigma. Precedentes dessa Turma Recursal Criminal. CORREIÇÃO DEFERIDA. (Correição Parcial $\mathrm{N}^{\circ}$ 71007210909, Turma Recursal Criminal, Turmas Recursais, Relator: Keila Lisiane Kloeckner Catta-Preta, Julgado em 30/10/2017) (grifei) 
Nesta esteira, ao que se depreende das ementas suso colacionadas, infere-se, em síntese, que a correição parcial colima a correção de decisões judiciais que não sejam impugnáveis por outros recursos, apresentando a inversão tumultuária de atos e fórmulas do processo, ou seja, erros de atividade, ferindo, assim, a ordem cronológica dos atos processuais: "A correição parcial é remédio que, teoricamente sem interferir com os atos decisórios, beneficia os litigantes que se aleguem vítimas de erros ou de abusos que invertam ou tumultuem a ordem dos atos processuais." (Henrique, texto digital, 2015, apud ASSIS, 2008).

Ainda, em abordagem deste tópico, coteja-se que a correição parcial tão somente destina-se a rever atos do julgador que impliquem nos referidos erros de atividade, não havendo rediscussão do mérito ou conflitos de interesse exauridos em primeira instância. Logo, não faz coisa julgada, em face de que não é ação, a correição parcial, pelo que não enseja a instauração de novo processo judicial ou reapreciação de matéria de mérito (HOMMERDING, texto digital, 2012).

\section{ABORDAGEM HISTÓRICA}

Segundo Moreira (texto digital, 2011, apud ASSIS, 2008, p. 881): “o remédio tem raízes num texto assaz vago das ordenações Filipinas e de fato originou-se do art. 669, $\S 5^{\circ}$ do regulamento 737 de 1850. Passou ao art. 143, §6 do Dec. 9.263, de 22.12.1911 [...] já com o nome próprio de correição parcial.".

Todavia, em linha diversa de pensamento, Moreira (texto digital, 2011, apud SANTOS, 2002, p.29), ressalta que "ao tratar da evolução histórica da correição parcial deixou claro se deve buscar no direito romano a figura mais remota desse instituto.", sendo derivada da "supplicatio"3, pelo que não possui relação com reclamação prevista nas Ordenações Filipinas. Neste mesmo teor, Hommerding (texto digital, 2012), aduz que a correção parcial tem sua origem na legislação de Roma, dado que surgiu com o nome de "supplicatio", e objetivava dar ciência ao Imperador sobre as irregularidades processuais cometidas pelos juízes.

A seguir, teria surgido em Portugal, com o escopo de atender tais necessidades romanas acerca das irregularidades processuais, além de preencher a inexistência de recursos, conforme explica Hommerding (texto digital, 2012). No que tange ao Brasil, a correição parcial se apresenta como uma "reminiscência" do período colonial, que veio para este território com as Ordenações Manuelinas, prosseguindo, após, com as Ordenações Afonsinas e Filipinas, sendo que, nesta última, a correição passou a ser exercida pelos

3 Trata-se de meio de impugnação das decisões no Direito Romano, que surgiu posteriormente à apelação, sendo mais remoto, inclusive, do que o agravo, eis que constituiu fonte da primitiva "sopricação", o qual, por seu turno, originou o agravo ordinário previsto no Código Manuelino. 
Corregedores. Com a independência do estado brasileiro, evolui e recebe nova roupagem com o advento da República através da primeira Constituição República de 1891.

Ainda, com a bifurcação do meio processual em estadual e federal, de acordo com Hommerding (texto digital, 2012), foi possível às diversas justiças estaduais, conforme leis de organização judiciária local, criar e estipular o instituto da correição, não sendo mais possíveis "revisões impertinentes e constantes dos atos dos juízes, fora dos recursos ordinários, mesmo diante de decisões erradas." (Hommerding, texto digital, 2012, apud PRADO KELLY). Desta forma, tem-se o surgimento da correição parcial, destarte, em leis estatuais e de organização judiciária.

\section{NATUREZA JURÍDICA}

Sendo questão de grande divisão doutrinária, há aqueles que defendem tratar-se a correição parcial de providência ou medida disciplinar, enquanto que outros, sustentam ser um recurso administrativo ou, ainda, entender configurar-se um "sucedâneo recursal", que equivaleria a uma categoria intermediária de recursos e medidas administrativas, conforme explica Avena (texto digital, 2015).

Em visão oposta, infere-se que Nucci (texto digital, 2015) argumenta ser um "autêntico recurso" em face de possuir o julgamento e processamento por câmara ou turma dos Tribunais, ensejando, inclusive, a adoção de alguma medida contra o magistrado. Logo, colimando rediscutir e questionar a decisão proferida pelo órgão jurisdicional $a$ quo ${ }^{4}$, não lhe retira a natureza recursal.

Ainda, segundo o referido jurista (texto digital, 2017), caso não tivesse a correição parcial a natureza recursal, não seria julgada pelas câmaras criminais, mas por órgão disciplinar do tribunal e, inclusive, pela Corregedoria-Geral de Justiça. Desta forma, assevera, Nucci, não ser esta a hipótese, uma vez que a Corregedoria possui função administrativa e fiscalizatória, não detendo competência para o proferimento de decisões jurisdicionais relacionadas aos processos judiciais.

Lado outro, Nucci (texto digital, 2017) refere, ademais, que na Justiça Federal predomina entendimento distinto em algumas regiões, como é o caso do Regimento Interno do Conselho da Justiça Federal da 3. ${ }^{a}$ Região, em seu art. 1. ${ }^{\circ}$, que assim dispõe: "O Conselho da Justiça Federal da 3. ${ }^{a}$ Região é o órgão do Tribunal Regional Federal incumbido de presidir, nos territórios dos Estados de São Paulo e Mato Grosso do Sul, a administração da Justiça Federal de Primeira Instância". Inobstante, o art. $4 .^{\circ}$, I, prevê como de sua competência "decidir correição parcial, requerida pela parte ou pela Procuradoria da República, no

4 Juízo de origem. 
prazo de cinco dias, contra ato ou despacho de juiz de que não caiba recurso, ou omissão que importe erro de ofício ou abuso de poder (Lei 5.010/66, art. 6. ${ }^{\circ}$, caput, I).

Diante disso, muitos juristas criticam esta posição, tendo em vista que a Corregedoria é órgão de cunho eminentemente administrativo e fiscalizador (disciplinar), não sendo plausível a ampliação de suas funções e/ ou competências, uma vez que possui caráter diverso da função jurisdicional, a qual é exclusiva do Estado na pessoa do Juiz, após o curso processual, com eventual rediscussão por câmaras ou turmas do próprio tribunal.

\section{PREVISÃO LEGAL}

A correição parcial possui respaldo legal no art. 6 . $^{\circ}$ I, da Lei 5.010/1966. Também, segundo Nucci (texto digital, 2015), vem prevista e disciplinada pelos Regimentos Internos dos Tribunais. De outra banda, há aqueles que alegam a sua inexistência no âmbito recursal, por não estar prevista no Código de Processo Penal. O renomado jurista salienta, ainda, a existência de fundamento legal, diante da finalidade de atacar decisões judiciais que tumultuem o regular andamento do processo, ocasionando a prática de erros procedimentais pelo julgador.

Outrossim, no mesmo sentido, Avena (texto digital, 2015) comunga de que a única previsão existente é a aquela disposta no art. 6. ' , I, da Lei 5.010/1966, que organiza a Justiça Federal de 1. ${ }^{\text {a }}$ instância, a qual admite a propositura pela parte ou Ministério Público perante o Conselho da Justiça Federal, visando combater ato ou despacho que não caiba recurso ou que importe erro de ofício ou abuso de poder.

Entretanto, com a promulgação da Lei 8.472/1992, que, no art. 5. ${ }^{\circ}$, reorganizou as competências do Conselho da Justiça Federal, há doutrinadores e juristas que entendem e defendem o posicionamento de que a correição foi afastada, posto que tal estatuto legal sequer faz qualquer menção a ela.

Contudo, apesar disso, Avena (texto digital, 2015) explicita que é possível a correição parcial para reanalisar decisões prolatadas na esfera dos Juizados Especiais Criminais, sendo competentes as Turmas Recursais para o seu julgamento.

\section{DA (IN)CONSTITUCIONALIDADE DA CORREIÇÃO PARCIAL}

Conforme já sublinhado neste trabalho, há densa discussão acerca da constitucionalidade da correição parcial, eis que a medida em liça está assentada em nosso sistema processual, uma vez que disposta em lei federal (art. 6. ${ }^{\circ}$, I, Lei 5.010/1966), além de vir disciplinada em vários Regimentos Internos dos Tribunais (NUCCI, texto digital, 2015). 
Ao que se infere da legislação, a correição parcial encontra suporte em duas leis, consoante assevera a doutrina: na Lei 1.533/51 (art. 5. ${ }^{\circ}$, II), que versava acerca do mandado de segurança (atualmente substituída pela Lei 12.016/2009 e que não mais prevê a correição parcial), bem como na Lei 5.010/66 (art. 6. ${ }^{\circ}$, I), que regula a Justiça Federal de primeira instância; segundo ensinamentos de Nucci (texto digital, 2017). Assim, trata-se da única forma de considerar a correição como um recurso com amparo constitucional, ainda que o seu assentamento tenha ocorrido sob o arrimo da Lei 1.533/51.

Frisa-se, também, que o Código Judiciário de São Paulo (Decreto-lei complementar 3/69), nos arts. 93 a 96, reforça que apenas a União é quem detém competência para legislar sobre matéria processual, sendo, portanto, de âmbito nacional (art. 22, I, CF). De outra banda, não é caso de aplicação do art. 24, XI, da Constituição, que prevê a competência concorrente dos Estados juntamente com a União, de legislar a respeito de "procedimentos em matéria processual", visto que "criar um recurso" não configura, pois, a criação de um procedimento, em concordância com Nucci (texto digital, 2015).

Destarte, ante o exposto, insta explicitar que a correição parcial é medida que foi criada por legislação federal, sendo que o procedimento para sua interposição deve ser previsto por lei estadual. Logo, não há que se falar em inconstitucionalidade do uso desta via impugnativa, embora haja posições doutrinárias em contrário, defendendo ser a correição medida administrativa ou disciplinar; e, também, grande gama de juristas adotando a tese de ser a correição parcialmente inconstitucional, não sendo pertinente o seu uso em face de que as leis antes citadas tão somente versam acerca de sua existência, nada dispondo sobre a criação do recurso em si. Deste modo, é crível a existência da correição parcial, considerando a sua previsão originária nas leis federais anteriormente declinadas.

\section{DA LEGITIMIDADE ATIVA E PASSIVA}

Como legitimados ativos, tem-se as partes, interessados, o Ministério Público e o Corregedor-Geral de Justiça. Já, no que toca os legitimados passivos, de acordo com Hommerding (texto digital, 2012), tem-se que a correição parcial somente é cabível para atacar atos de juízes de primeira instância eivados de erros/vícios de atividade.

\section{DO RITO PROCESSUAL}

Alusiva à matéria procedimental da correição parcial, aquela vem capitulada nos regimentos internos dos tribunais estaduais e federais. Especificamente no regimento interno do Tribunal de Justiça do Rio Grande do Sul, há previsão do procedimento nos arts. 251 a 254 (com remição ao art. 195) da Lei Estadual n. ${ }^{\circ}$ 7.356/1980 - COJE, conforme expôe Avena (texto digital, 2015): “Art. 195. A correição parcial visa à emenda de erros ou abusos que 
importem na inversão tumultuária de atos e fórmulas legais, na paralisação injustificada dos feitos ou na dilatação abusiva de prazos, quando, para o caso, não haja recurso previsto em lei.".

No mais, alusivo ao rito a ser seguido, a posição dominante nos tribunais é a de que a correição parcial se conduz pelo rito do recurso em sentido estrito. Tal hipótese, outrossim, justifica-se tendo em vista a ausência de disposição legal neste sentido, uma vez que a Lei 1.533/51 (substituída pela Lei $12.016 / 2009$ ) e a Lei 5.010/66 tão somente apresentam irrisórias alusões acerca da existência da correição, sem pormenorizar o rito a seguir, segundo Nucci (texto digital, 2017).

Embora isso, Pimentel (texto digital, 2015 apud TOURINHO FILHO, 2011, p. 399), assevera que: “Queremos crer que o rito da correição é o do agravo de instrumento. A questão, contudo, não é pacífica. Há quem sustente que o procedimento deve ser o do recurso em sentido estrito, único que, no processo penal, serve para impugnar decisão interlocutória simples.". Logo, existem ambas as correntes doutrinárias em que, de um lado, sustentam que deve ser seguido o rito do recurso em sentido estrito, capitulado no Código de Processo penal, enquanto que parte da doutrina entende ser cabível o rito do agravo de instrumento previsto no Código de Processo Civil.

Decisões jurisprudenciais, neste teor, evidenciam que, notadamente, no Estado do Rio Grande do Sul, o Tribunal tem admitido a dedução da correição parcial seguindo o rito do recurso em sentido estrito:

CORREIÇÃO PARCIAL. DECISÃO QUE DETERMINOU AO MINISTÉRIO PÚBLICO QUE PROVIDENCIASSE O TRASLADO DAS PEÇAS NECESSÁRIAS À FORMAÇÃO DO RECURSO EM SENTIDO ESTRITO POR ELE INTERPOSTO. INVERSÃO TUMULTUÁRIA CONFIGURADA. A determinação de que o Ministério Público providenciasse no traslado das peças necessárias à formação do recurso em sentido estrito por ele interposto importa em inversão tumultuária de atos e fórmulas legais, uma vez o rito do recurso em sentido estrito, com previsão nos artigos 587 e 588 do Código de Processo Penal, estabelece como atribuição do escrivão o traslado das peças processuais indicadas pela parte recorrente. LIMINAR CONFIRMADA. CORREIÇÃO PARCIAL DEFERIDA EM DEFINITIVO. (Correição Parcial $\mathrm{N}^{\circ}$ 70071616999, Quinta Câmara Criminal, Tribunal de Justiça do RS, Relator: Cristina Pereira Gonzales, Julgado em 30/11/2016) (grifei)

CORREIÇÃO PARCIAL. TRASLADO PARA FORMAÇÃO DO AGRAVO EM EXECUÇÃO. ATRIBUIÇÃO DO ESCRIVÃO DA VARA. INVERSÃO TUMULTUÁRIA CONFIGURADA. Seguindo o agravo em execução o mesmo rito do recurso em sentido estrito, consoante entendimento pacificado no STJ, cabe ao Escrivão da 
Vara o traslado das cópias para a formação do instrumento do agravo em execução, não podendo tal encargo ser transferido para a parte, ainda que difícil a situação da serventia, que se ressente com o reduzido número de funcionários e o elevado número de processos. LIMINAR CONFIRMADA. CORREIÇÃO PARCIAL DEFERIDA. (Correição Parcial No 70061549457, Quinta Câmara Criminal, Tribunal de Justiça do RS, Relator: Cristina Pereira Gonzales, Julgado em 12/11/2014) (grifei)

\footnotetext{
CORREIÇÃO PARCIAL. AGRAVO EM EXECUÇÃO. FORNECIMENTO DAS CÓPIAS INDICADAS E OBRIGATÓRIAS PARA TRANSLADO. 1. O Ministério Público postula a cassação da decisão que determinou que o agravante fornecesse as cópias indicadas e as necessárias à formação do agravo em execução. 2. No agravo em execução, o rito a ser adotado é o previsto para o recurso em sentido estrito, o qual, segundo o art. 587 do CPP, quando o recurso houver de subir por instrumento, incumbe a parte indicar, tão-somente, no termo de sua interposição ou em requerimento avulso, as peças dos autos de que pretenda traslado. 3. É atribuição da serventia cartorária a extração de cópia das peças indicadas, na interposição do agravo em execução, e das peças obrigatórias. CORREIÇÃO PROCEDENTE. (Correição Parcial No 70057700254, Primeira Câmara Criminal, Tribunal de Justiça do RS, Relator: Julio Cesar Finger, Julgado em 18/12/2013) (grifei)
}

Ademais, em contrapartida, aos Estados é permitido legislar sobre teor procedimental em matéria processual, sob a ótica da competência concorrente (CF, art. 24, XI), em face da lacuna legal, ora verificada, no que diz respeito ao processamento da correição.

\section{PRAZO}

Consoante esclarece Avena (texto digital, 2015), o prazo para dedução do pedido de correição parcial, com fundamento da Lei 5.010/1966, é de cinco dias, que se contam da data da ciência do despacho ou decisão impugnada, mais dois dias para a apresentação das razões. Em âmbito estadual, caso não haja lei prevendo o prazo para interposição, deverá ser seguido o mesmo prazo de cinco dias.

Conquanto haja posição doutrinária entendendo pelo rito do agravo de instrumento, previsto no Código de Processo Civil, a ser seguido pela correição parcial, insta referir que, em sendo tal hipótese de incidência, o prazo para interposição será de quinze dias, sendo que as razões já deverão acompanhar a medida requerida (art. 1.003, $\S 5^{\circ}, \mathrm{CPC}$ ). 


\section{DO PROCESSAMENTO}

Já visto que a correição parcial tende a seguir o rito do recurso em sentido estrito, previsto no Código de Processo Penal, art. 581, vislumbra-se que a sua dedução se dá pelo corrigente através de petição fundamentada e instruída, dirigindo-se ao Presidente do Tribunal a que sujeito o magistrado prolator da decisão impugnada (NUCCI, texto digital, 2017). Uma vez presentes os requisitos, ter-se-á a admissão da medida.

A seguir, o presidente do respectivo tribunal proceder-se-á ao exame atinente à necessidade e/ou possibilidade de deferir medida liminar eventualmente requerida, condicionada a presença de fundamentos relevantes, bem como havendo a existência de perigo de prejuízo irreparável em razão da não suspensão dos efeitos do ato impugnado.

Havendo ou não deferimento, implicará na distribuição do pedido perante o órgão colegiado competente para o seu julgamento, que será a Câmara ou Turma, com a remessa ao relator, este que poderá, inclusive, requisitar informações ao juízo a quo. Em se tratando de medida que apresenta caráter de urgência, tais informações poderão ser dispensadas pelo relator, desde que o pedido esteja com a devida instrução probatória.

Da mesma maneira, ao juiz, quando do recebimento do pedido de informações, é facultada a retratação da decisão (efeito regressivo), hipótese em que a correição restará prejudicada. Ato contínuo, mister o parecer do Ministério Público e, por fim, o julgamento da medida proposta, comunicandose o magistrado.

De uma forma geral e ampla, tal esboço é o que ocorrerá quando da dedução da correição parcial. No entanto, impende referir que existem diferentes posições procedimentais a depender dos tribunais a nível estadual. Como exemplo, tem-se no caso do Estado de São, em que o Regimento Interno daquele tribunal estipula que à correição parcial seja aplicada o rito do agravo de instrumento previsto pelo Código de Processo Civil (art. 1.015), ainda que se trate de matéria de ordem criminal. Além da possibilidade, inclusive, de o relator determinar a suspensão liminar da decisão que ensejou a propositura do pedido correicional, caso do ato impugnado possa advir ineficácia da medida (arts. 211 a 215 do RITJSP).

Apesar disso, e nesta esteira, afere-se que o art. $195, \S 6 .^{\circ}$, a, da Lei 7.356/1980 - Código de Organização Judiciária do Rio Grande do Sul, erige a viabilidade de suspensão liminar da medida acautelatória, em caso de relevância dos fundamentos do pedido e se houver possibilidade de prejuízo em caso de retardamento (NUCCI, texto digital, 2017).

Repisa-se, ao fim, que não é possível a interposição de recurso extraordinário perante o Supremo Tribunal Federal, na hipótese de deferimento ou indeferimento da correição parcial, diante da natureza administrativa desta, a qual carece de conteúdo jurisdicional. 


\section{EFEITOS}

Assim como nos demais recursos e meios de impugnação das decisões judiciais, a correição parcial possui o efeito devolutivo, que devolve a reapreciação da matéria processada e julgada a tribunal de superior instância. Entretanto, importa esclarecer que no caso da correição, não haverá a reanálise da matéria de mérito ou conflito de interesses, mas, tão somente, o reexame de atos do juiz que impliquem em erro de atividade ou erro procedimental.

Ademais, não exibe efeito suspensivo, como regra geral. No entanto, o art. 9. ${ }^{\circ}$ da Lei 5.010/1966 possibilita ao relator da correição parcial "ordenar a suspensão, até trinta dias, do ato ou despacho impugnado, quando de sua execução possa decorrer dano irreparável". Em se tratando da Justiça Estadual, tal hipótese de sobrestamento dependerá da existência de eventual norma de organização judiciária local prevendo a suspensão, segundo elucida Avena (texto digital, 2015).

No mais, verifica-se que a jurisprudência vem conferindo efeito regressivo à correição parcial:

CORREIÇÃO PARCIAL. TRASLADO DE PEÇAS PARA FORMAÇÃODE AGRAVOEMEXECUÇÃOPENAL.ATRIBUIÇÃO DO ESCRIVÃO, E NÃO DA PARTE AGRAVANTE. MEDIDA PREJUDICADA. RETRATAÇÃO DO JUÍZO DE PRIMEIRO GRAU. Em regra, ao agravo em execução aplica-se a normatização do recurso em sentido estrito, cabendo ao agravante apenas indicar as peças para compor o instrumento, sendo do escrivão judicial a responsabilidade pela extração das peças indicadas pela parte - no caso, o Ministério Público. Inteligência dos arts. 587, 588, 589 e 590, todos do CPP, bem como no art. 106 do COJE. No caso concreto, sobreveio informações dando conta de que o juízo de primeiro grau se retratou, restando prejudicada a análise da presente medida correicional. CORREIÇÃO PARCIAL PREJUDICADA. (Correição Parcial No 70062235494, Quinta Câmara Criminal, Tribunal de Justiça do RS, Relator: Lizete Andreis Sebben, Julgado em 07/11/2014) (grifei)

CORREIÇÃO PARCIAL. OBJETO ATENDIDO EM JUÍZO DE RETRATAÇÃO. PREJUDICADA. UNÂNIME. (Correição Parcial $\mathrm{N}^{\circ}$ 70068414234, Quarta Câmara Criminal, Tribunal de Justiça do RS, Relator: Aristides Pedroso de Albuquerque Neto, Julgado em 07/04/2016) (grifei)

CORREIÇÃO PARCIAL. ATUALIZAÇÃO DE ANTECEDENTES CRIMINAIS. Considerado o juízo de retratação procedido na origem, prejudicada resulta a medida intentada neste grau de jurisdição. JULGADA PREJUDICADA A CORREIÇÃO PARCIAL. 
(Correição Parcial N $N^{o}$ 70041225343, Sexta Câmara Criminal, Tribunal de Justiça do RS, Relator: Cláudio Baldino Maciel, Julgado em 31/03/2011) (grifei)

Logo, de acordo com Avena (texto digital, 2015), tal efeito permite ao juízo a quo a reconsideração de sua decisão, tendo em vista o pedido de informações pelo Tribunal competente para o processamento e julgamento da medida deduzida.

\section{CONSIDERAÇÕES FINAIS}

Com a realização deste estudo foi possível verificar que a correição parcial, medida a ser interposta contra ato do magistrado, conforme defende a doutrina majoritária, visa sanar eventual tumulto processual ou eventual burla do normal andamento do processo. Este instituto apresenta várias polêmicas e divergências entre a doutrina, seja relativo à sua (in)constitucionalidade, seja em relação ao rito processual a seguir, prazos processuais ou natureza jurídica.

De outra banda, conferiu-se que este instrumento surgiu no período colonial, passando a ser aplicado, desde então, como forma de corrigir e impugnar as irregularidades processuais cometidas pelos julgadores, uma vez que inexistiam recursos específicos para tais finalidades. Inobstante, apesar de não possuir previsão expressa na Constituição Federal de 1988, possui amparo legal (quanto à sua existência) na Lei 5.010/1966. Anteriormente, a Lei 1.533/51, que versava acerca do mandado de segurança, trazia sucinta previsão acerca da correição. No entanto, com o advento da Lei 12.016/2009, que substituiu a legislação anterior, aquela nada menciona acerca da correição parcial, razão pela qual diversos juristas defendem pela inconstitucionalidade do instituto.

Entretanto, sendo a correição medida criada por legislação federal, a qual apenas refere sobre sua existência, incumbe aos estados legislar a respeito do procedimento a ser adotado. Desta forma, há outra corrente doutrinária, conforme esposado no decorrer do trabalho, que sustenta pela sua constitucionalidade, eis ser possível a dedução da correção, tendo em vista a sua previsão originária na legislação federal anteriormente citada, a qual pode ser complementada através da competência concorrente dos estados no que tange ao procedimento.

Há que se salientar, inclusive, que além desta divergência, grande parte da doutrina argumenta tratar-se a correição parcial de medida contra atos do juiz, que possui como escopo corrigir os atos e/ou tumultos processuais, sem reavaliar o mérito da decisão, visto que não faz coisa julgada, tampouco instaura novo processo. Logo, não possuindo natureza recursal. Todavia, há vasta parte de juristas que entendem pela natureza recursal, em face de objetivar corrigir o trâmite processual, possuindo, inclusive, natureza residual. Permanece a discussão, sem entendimento pacífico. 
Ademais, vislumbrou-se que é adotado principalmente o rito do Recurso em Sentido em Estrito, previsto no Código de Processo Penal, no que tange ao seu processamento e prazos, embora haja Estados que sigam o rito do Agravo de Instrumento, expresso no Código de Processo Civil. Tal hipótese também não é pacífica na doutrina e nos tribunais, gerando diversas divisões práticas conforme o Estado brasileiro. Especificamente no Estado do Rio Grande do Sul, verifica-se que o rito predominantemente seguido por este Tribunal, é o rito do Recurso em Sentido em Estrito, posto basear-se em entendimentos firmados pelo Superior Tribunal de Justiça neste pretexto.

O prazo para sua interposição variará de acordo com o rito adotado, sendo que se for o rito do Recurso em Sentido em Estrito será de cinco dias para interposição, mais dois dias para apresentação das razões. Em sendo o rito do Agravo de Instrumento, caso adotado, deverá ser interposto em quinze dias, acompanhado das razões.

Alusivo aos efeitos, conferiu-se que apresenta o efeito devolutivo, sendo que a jurisprudência vem introduzindo o efeito regressivo à correição parcial, que permite o juízo de retratação do órgão $a$ quo.

Diante do exposto, embora não haja previsão deste instrumento na Constituição Federal, conclui-se tratar a correição de medida importante no âmbito do processo penal, a fim de atacar decisões do julgador que impliquem em prejuízo à parte, em face da inversão de atos e/ou tumulto processual, ora perpetrado, possuindo grande aplicação prática, consoante se constatou a partir das pesquisas jurisprudenciais.

\section{REFERÊNCIAS}

AVENA, Norberto. Manual de Processo Penal. 3. ed. rev., atual. e ampl. - Rio de Janeiro: Forense; São Paulo: Método: 2015.

BRASIL. Constituição da República Federativa do Brasil de 1988. Disponível em: <http://www.planalto.gov.br/ccivil_03/constituicao/constituicaocompilado.htm>. Acesso em: 26 nov. 2017.

BRASIL. Decreto-Lei n. ${ }^{\circ}$ 3.689, de 3 de outubro de 1941. Código de Processo Penal. Disponível em: <http://www.planalto.gov.br/ccivil_03/decreto-lei/ Del3689Compilado.htm>. Acesso em: 26 nov. 2017.

BRASIL. Lei 5.010, de 30 de maio de 1966. Organiza a Justiça Federal de primeira instância, e dá outras providências. Disponível em: <http://www.planalto.gov.br/ ccivil_03/leis/L5010.htm>. Acesso em: 26 nov. 2017.

BRASIL. Lei 12.016, de 7 de agosto de 2009. Disciplina o mandado de segurança individual e coletivo e dá outras providências. Disponível em: $<$ http:/ / www. planalto.gov.br/ccivil_03/_ato2007-2010/2009/lei/112016.htm>. Acesso em: 26 nov. 2017. 
BRASIL. Lei 13.105, de 16 de março de 2015. Código de Processo Civil. Disponível em: <http://www.planalto.gov.br/ccivil_03/_ato2015-2018/2015/lei/113105.htm>. Acesso em: 26 nov. 2017.

CHEMIN, Beatris Francisca. Manual da Univates para trabalhos acadêmicos: planejamento, elaboração e apresentação. 3. ed. - Lajeado: Ed. da Univates, 2015.

HENRIQUE, Diego. O Instituto da Correição Parcial. Jusbrasil, 2015. Disponível em: <https://diegodto.jusbrasil.com.br/artigos/196796271/o-instituto-da-correicaoparcial>. Acesso em: 25 nov. 2017.

HOMMERDING, Adalberto Narciso. RECLAMAÇÃO E CORREIÇÃO PARCIAL: CRITÉRIOS PARA DISTINÇÃO. Uri: Direito e Justiça, 2012. Disponível em: <http:/ / docplayer.com.br/21799944-Reclamacao-e-correicao-parcial-criterios-paradistincao-partial-claim-and-correction-criteria-for-distinction-adalberto-narcisohommerding-1.html>. Acesso em: 25 nov. 2017.

KRIEGER, Mauricio Antonacci. Processo do Trabalho: da correição parcial. Conteúdo Jurídico: 2016. Disponível em: <http:/ / conteudojuridico.com. br / colunas\&colunista=30213_Mauricio_Krieger\&ver=2339>. Acesso em: 03 dez. 2017.

LUSTOSA, Dayane Sanara de Matos. Pronunciamento acerca dos recursos no processo penal brasileiro. Conteúdo Jurídico: 2010. Disponível em: <http:/ / www. conteudojuridico.com.br/artigo,pronunciamento-acerca-dos-recursos-no-processopenal-brasileiro,26666.html>. Acesso em: 26 nov. 2017.

MOREIRA, Fabio De Almeida. Correição Parcial. Jurisway, 2011. Disponível em: <https://www.jurisway.org.br/v2/dhall.asp?id_dh=5282>. Acesso em: 25 nov. 2017.

NUCCI, Guilherme de Souza. Código de Processo Penal comentado. 16. ed. rev., atual. e ampl. - Rio de Janeiro: Forense, 2017.

NUCCI, Guilherme de Souza. Manual de processo penal e execução penal. 14. ed. rev., atual. e ampl. - Rio de Janeiro: Forense, 2017.

NUCCI, Guilherme de Souza. Processo penal. 3. ed. rev., atual. e ampl. - Rio de Janeiro: Forense, 2015. (Esquemas \& sistemas; v. 3).

ORTEGA, Flávia Teixeira. O que mudou no agravo de instrumento no Novo CPC? Jusbrasil: 2016. Disponível em: <https:/ / draflaviaortega.jusbrasil.com.br/ noticias / 406252734/o-que-mudou-no-agravo-de-instrumento-no-novo-cpc $>$. Acesso em: 26 nov. 2017.

PEÑA, Eduardo Chemale Selistre. O recurso de agravo como meio de impugnação das decisões interlocutórias de primeiro grau. Porto Alegre, PUC/2006. Disponível em: <http:/ / tede2.pucrs.br/tede2/bitstream/tede/4048/1/384784.pdf >. Acesso em: 26 nov. 2017. 
PIMENTEL, Nilberto Montino. Recursos Criminais: Espécies e as hipóteses de cabimento. Conteúdo Jurídico: 2015. Disponível em: <http:/ / www.conteudojuridico. com.br/artigo,recursos-criminais-especies-e-as-hipoteses-de-cabimento,52847.html>. Acesso em: 26 nov. 2017.

RIO GRANDE DO SUL. Lei 7.356, de $1^{\circ}$ de fevereiro de 1980. Dispõe sobre o Código de Organização Judiciária do Estado. Disponível em: <http:/ / www.al.rs.gov.br/ legiscomp/arquivo.asp?Rotulo=Lei\%20n\%BA\%207356\&idNorma=948\&tipo=pdf $>$. Acesso em: 26 nov. 2017.

RIO GRANDE DO SUL. Tribunal de Justiça. Correição Parcial nº 70075406900, da Quarta Câmara Criminal, Tribunal de Justiça do RS. Requerente: D. P. S. Requerido: Juiz de Direito da $2^{\text {a }}$ Vara Criminal - Juizado do Torcedor Porto Alegre. Relator Julio Cesar Finger. Porto Alegre, 09 nov. 2017. Disponível em: <https:/ /www.tjrs.jus.br/ site/jurisprudencia/>. Acesso em: 26 nov. 2017.

RIO GRANDE DO SUL. Tribunal de Justiça. Correição Parcial n ${ }^{\circ}$ 71007210909, da Turma Recursal Criminal, Turmas Recursais. Corrigente: Ministério Público. Corrigendo: Juiz de Direito da Vara Judicial Comarca Flores da Cunha. Relator Keila Lisiane Kloeckner Catta-Preta. Porto Alegre, 30 out. 2017. Disponível em: <https:/ / www.tjrs.jus.br/site/jurisprudencia/>. Acesso em: 26 nov. 2017.

RIO GRANDE DO SUL. Tribunal de Justiça. Correição Parcial nº 70062235494, da Quinta Câmara Criminal, Tribunal de Justiça do RS. Requerente: Ministério Público. Requerido: Juiza de Direito da VEC da Comarca de Carazinho. Relator Lizete Andreis Sebben. Porto Alegre, 07 nov. 2014. Disponível em: <https:/ /www.tjrs.jus.br/site/ jurisprudencia/>. Acesso em: 26 nov. 2017.

RIO GRANDE DO SUL. Tribunal de Justiça. Correição Parcial nº 70068414234, da Quinta Câmara Criminal, Tribunal de Justiça do RS. Requerente: Ministério Público. Requerido: Juiza de Direito da Comarca de Flores da Cunha. Relator Aristides Pedroso de Albuquerque Neto. Porto Alegre, 07 abr. 2016. Disponível em: <https:/ / www.tjrs.jus.br/site/jurisprudencia/>. Acesso em: 26 nov. 2017.

RIO GRANDE DO SUL. Tribunal de Justiça. Correição Parcial n ${ }^{\circ}$ 70041225343, da Sexta Câmara Criminal, Tribunal de Justiça do RS. Requerente: C. R. K. Requerido: J.D.1. C.C.S.L. Relator Cláudio Baldino Maciel. Porto Alegre, 31 mar. 2011. Disponível em: <https://www.tjrs.jus.br/site/jurisprudencia/> . Acesso em: 26 nov. 2017.

RIO GRANDE DO SUL. Tribunal de Justiça. Correição Parcial n ${ }^{0}$ 70061549457, da Quinta Câmara Criminal, Tribunal de Justiça do RS. Requerente: Jocemar Rovea. Requerido: Juiz de Direito da Vara de Execução Criminais da Comarca de Lagoa Vermelha. Relator Cristina Pereira Gonzales. Porto Alegre, 12 nov. 2014. Disponível em: <https:/ / www.tjrs.jus.br/site/jurisprudencia/>. Acesso em: 26 nov. 2017.

RIO GRANDE DO SUL. Tribunal de Justiça. Correição Parcial no 70071616999, da Quinta Câmara Criminal, Tribunal de Justiça do RS. Requerente: Ministério Público. Requerido: Juíza de Direito da $1^{\mathrm{a}}$ Vara Criminal da Comarca de Viamão. Relator 
Cristina Pereira Gonzales. Porto Alegre, 30 nov. 2016. Disponível em: <https://www. tjrs.jus.br/site/jurisprudencia/>. Acesso em: 26 nov. 2017.

RIO GRANDE DO SUL. Tribunal de Justiça. Correição Parcial nº 70057700254, da Primeira Câmara Criminal, Tribunal de Justiça do RS. Requerente: Ministério Público. Requerido: Juiz de Direito da Vara de Execuções Criminais da Comarca de Lajeado. Relator Relator Cláudio Baldino Maciel. Porto Alegre, 18 dez. 2013. Disponível em: <https://www.tjrs.jus.br/site/jurisprudencia/>. Acesso em: 26 nov. 2017.

RIO GRANDE DO SUL. Tribunal de Justiça. Correição Parcial n ${ }^{\circ}$ 70069612695, da Primeira Câmara Criminal, Tribunal de Justiça do RS. Requerente: Igor Inacio dos Santos da Silva. Requerido: Juiz de Direito da Vara de Execuções Criminais da Comarca de Itaqui. Relator Jayme Weingartner Neto. Porto Alegre, 08 jun. 2016. Disponível em: <https://www.tjrs.jus.br/site/jurisprudencia/>. Acesso em: 26 nov. 2017.

ROSA, Alexandre Morais. A controvérsia sobre as razões recursais em segundo grau. Conjur, 2016. Disponível em: <https://www.conjur.com.br/2016-dez-30/limitepenal-controversia-razoes-recursais-segundo-grau>. Acesso em: 25 nov. 2017.

SÃO PAULO. Decreto-Lei Complementar n. 3, de 27 de agosto de 1969.

Código Judiciário do Estado de São Paulo. Disponível em: <http:/ / www.al.sp. gov.br/repositorio/legislacao/decreto.lei.complementar/1969/decreto.lei. complementar-3-27.08.1969.html>. Acesso em: 26 nov. 2017.

SILVA, Adilson Siqueira Da. Teoria Geral dos Recursos. Jurisway: 2009. Disponível em: <https://www.jurisway.org.br/v2/dhall.asp?id_dh=2357>. Acesso em: 26 nov. 2017. 